$\begin{array}{r}\text { DARMABAKTI CENDEKIA: } \\ \text { Journal of Community Service and Engagements } \\ \text { www.e-journal.unair.ac.id/index.php/DC } \\ \hline\end{array}$

\section{PROMOTION MIX TRAINING AS A PREPARATION OF BAMBOO HANDICRAFT EDUCATIONAL TOUR LAUNCHING FOR UMKM AT SUMBERREJO DISTRICT, BOJONEGORO, EAST JAVA}

\author{
PELATIHAN BAURAN PROMOSI PADA UMKM SEBAGAI \\ PERSIAPAN PELUNCURAN WISATA EDUKATIF KERAJINAN \\ BAMBU KECAMATAN SUMBERREJO, KABUPATEN \\ BOJONEGORO, JAWA TIMUR
}

Scope:

Social Economy

\author{
Maurisia Putri Permatasari ${ }^{1^{*}}$, Annysa Endriastuti ${ }^{2}$ \\ ${ }^{1}$ Study Program of Marketing Management, Department of Business, Faculty of Vocational Studies, Universitas Airlangga, Surabaya-Indonesia \\ ${ }^{2}$ Study Program of English Language, Department of Business, Faculty of Vocational Studies, Universitas Airlangga, Surabaya-Indonesia
}

\begin{abstract}
$A B S T R A C T$
Background: This community service is a follow up of community service in Kecamatan Sumberrejo in 2017 and is expected to be the first step to preparing the launching of the bamboo tourism village in Kecamatan Sumberrejo. Purpose: This community service aims to provide solutions for problems faced by partners, preparation for launching and planning the right promotional mix to attract consumers' interest in the newly formed educational tourism in Kecamatan Sumberrejo. Method: Assistance by the team to partners through counseling, training, and practical assistance. In addition, worksheets have been provided to monitor partner activities and measure the effectiveness of the training. Result: The pre-test and post-test results illustrate an increase in partner knowledge regarding the promotion mix. Conclusion: The material delivered by the team was able to be well understood by partners and partners' knowledge and interest in marketing through the promotion mix increased.
\end{abstract}

\author{
ART I CLE INFO \\ Recieved 15 November 2019 \\ Accepted 10 Desember 2019 \\ Online 28 Juni 2020 \\ *Correspondence (Korespondensi): \\ Maurisia Putri Permatasari \\ E-mail: \\ maurisiaputri@vokasi.unair.ac.id
}

Keywords:

Marketing; Promotion Mix; Product Development Technology

Kata kunci:

Pemasaran; Bauran Promosi; Pengembangan Produk 


\section{PENDAHULUAN}

Kecamatan Sumberrejo merupakan salah satu kecamatan di Kabupaten Bojonegoro yang memiliki potensi bisnis yang menarik. Berbagai industri skala kecil dan rumahan berkembang cukup baik di beberapa desa di Kecamatan Sumberrejo. Industri rumahan mulai berkembang pesat seiring adanya kesadaran warga masyarakat untuk meningkatkan taraf hidup dengan cara yang dapat dijangkau. Keinginan untuk menghasilkan uang meskipun tanpa meninggalkan rumah biasanya dialami oleh ibu-ibu rumah tangga yang merasa berat untuk meninggalkan rumah namun ingin membantu perekonomian keluarga. Selain membuat produk untuk disetor ke pabrik-pabrik, masyarakat mulai sadar akan pentingnya memiliki usaha sendiri meskipun masih dalam skala rumahan.

Salah satu desa yang telah memiliki industri rumahan adalah Desa Sumuragung. Desa Sumuragung terkenal dengan produk kerajinan bambu yang telah dijalankan secara turun temurun. Keterampilan membuat produk berdasar bahan bambu pada umumnya diajarkan oleh orang tua kepada anak-anak dan cucunya. Produk yang dihasilkan sebagian besar berupa produk konvensional rumah tangga sesuai dengan kebiasaan pengolahan bambu yang telah dilakukan sejak dahulu. Banyak jenis kerajinan tangan yang dibuat dari bambu itu, di antaranya tampah, bojok, tompo (wadah untuk mencuci beras), kalo (wadah untuk memeras santan), dan kemarang (wadah untuk menaruh nasi) (Alfiyana, 2018).

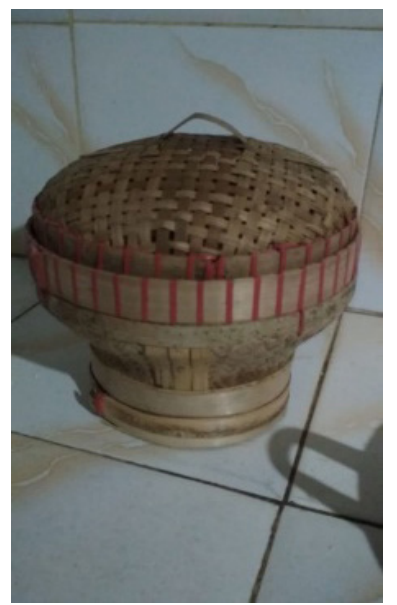

Gambar 1. Contoh produk kemarang

Gambar 1. merupakan salah satu contoh produk yang dihasilkan perajin bambu di Desa Sumuragung. Selain produk-produk konvensional, perajin bambu juga mulai memproduksi hiasanhiasan yang digunakan untuk acara khusus seperti karnaval dan pesta kemerdekaan Indonesia. Pada tahun 2017, tim kami pernah melaksanakan pengabdian kepada masyarakat di Kecamatan Sumberrejo dengan judul IbM Penyelarasan Akun Media Sosial sebagai Alat Pemasaran bagi Perajin Batik dan Anyaman Bambu di Kecamatan Sumberrejo, Kabupaten Bojonegoro, Jawa Timur. Hasil dari pelatihan di tahun 2017 menunjukkan peningkatan pengetahuan pada mitra terkait sarana pemasaran melalui media social. Namun sesuai hasil evaluasi oleh tim dan mitra, disimpulkan bahwa perajin bambu masih perlu pelatihan lebih lanjut mengenai ide inovasi produk dan implementasi bauran promosi melalui berbagai media. Sedangkan untuk mitra perajin batik telah mampu memanfaatkan media sosial sesuai dengan materi pelatihan yang telah diberikan oleh tim.

Setelah dilakukan kunjungan dan survey dari tim ke Kecamatan Sumberrejo, didapatkan pula kelompok pelaku usaha pengolahan makanan berbahan baku singkong di Desa Sumuragung. Olahan makanan yang dihasilkan bervariasi dan mulai dikenalkan ke pasaran. Salah satu makanan adalah bola-bola singkong yang diberi isian kekinian dan disesuaikan dengan selera kaum muda saat ini. Olahan singkong yang biasanya dipandang sebelah mata kini mampu menjadi salah satu makanan yang cukup digemari masyarakat. Berikut merupakan contoh salah satu produk olahan singkong yang dihasilkan:

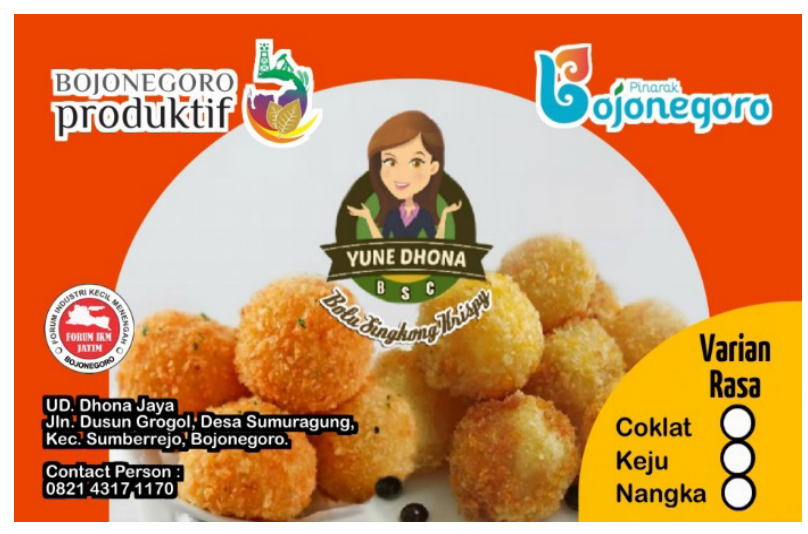

Gambar 2. Contoh Produk Olahan Singkong

Pada dasarnya, kedua mitra membentuk bisnis berdasarkan pada produk unggulan daerah yaitu singkong dan bambu. Desa Sumuragung berfokus pada pemberdayaan masyarakat melalui pemanfaatan hasil bumi yang terdapat di sekitar lingkungan desa. Sebagai usaha untuk tetap mendukung usaha rumahan dapat terus berputar, Desa Sumuragung merancang pemngembangan desa wisata kerajinan dari bambu yang dilengkapi pula dengan spot foto dan spot edukasi. Awal pertama muncul ide ingin mengeksplore Dukuh Grogol adalah 'Dulur Rukun'. Dulur Rukun adalah sekelompok pemuda-pemudi setempat yang 
selalu kompak menyemarakkan Dukuh Grogol. Sesuai ciri khas dukuh tersebut sebagai penghasil kerajinan yang terbuat dari bambu, wisata tersebut dinamakan 'Wisata Perajin Bambu' dan akan dilaunching pada awal tahun 2019 mendatang (Alfiyana, 2018). Tahap persiapan telah dilakukan dan direncanakan akan launching pada bulan Maret 2019.

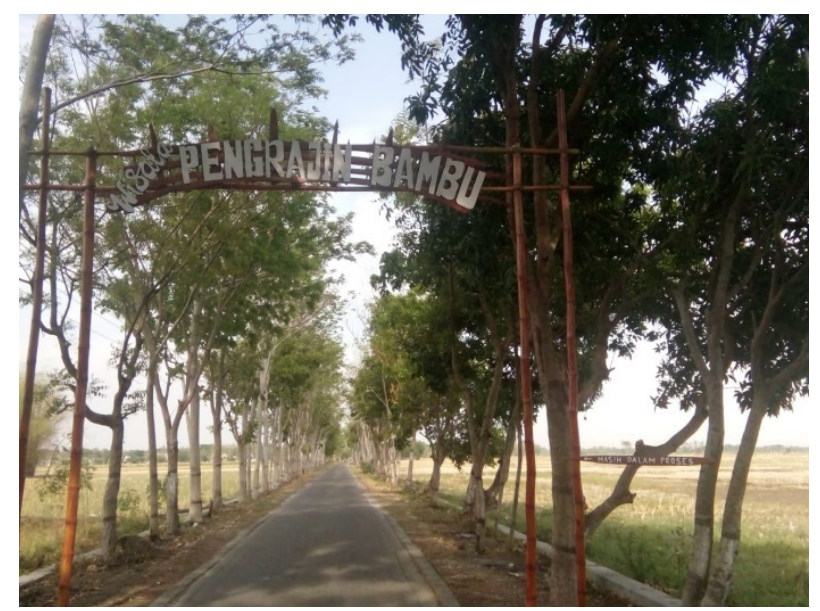

Gambar 3. Gapura Masuk Desa Wisata Sumuragung

Pemandangan alam yang indah turut menjadi pendukung untuk menarik minat wisatawan dating ke Desa Sumuragung dan menikmati suasana yang menyenangkan sekaligus mengenalkan aktivitas pengrajin bambu serta pengetahuanpengetahuan yang dikemas menarik dalam wisata edukatif kerajinan bambu.

Proses pendirian desa wisata ini tentu tidak lepas dari berbagi masalah yang timbul karena beberapa keterbatasan yang dimiliki oleh mitra. Salah satu permasalahan yang terungkap adalah kesulitan dalam penentuan produk yang akan dikenalkan supaya desa wisata selalu up to date dan tidak membosankan. Pengembangan produk dirasa masih menjadi salah satu masalah karena mitra terbiasa dengan memproduksi barang konvensional. Selain itu aspek pemasaran lain yang dianggap sebagai kesulitan oleh mitra adalah aspek promosi. Sarana-sarana promosi yang tepat dibutuhkan untuk dapat menarik lebih banyak wisatawan untuk berkunjung ke desa wisata di Desa Sumuragung. Sinergi antara kedua mitra tentu dibutuhkan untuk dapat mendukung kesuksesan Desa Wisata Sumuragung. Produk olahan singkong diharapkan mampu menjadi salah satu komponen daya tarik dan dapat dijadikan oleh-oleh khas saat mengunjungi desa wisata tersebut.

Program pengabdian kepada masyarakat ini diharapkan menjadi tindak lanjut dari pelaksanaan pengabdian kepada masyarakat di Kecamatan Sumberrejo pada tahun 2017 lalu. Selain itu, diharapkan pelatihan yang akan dilakukan dapat menjadi langkah awal untuk pendampingan persiapan launching Desa Wisata Pengrajin Bambu di Desa Sumuragung, Kecamatan Sumberrejo, Kabupaten Bojonegoro.

Berdasarkan analisis situasi yang telah digambarkan serta hasil diskusi tim pengusul dengan mitra, dapat disimpulkan beberapa permasalahan prioritas yang dihadapi oleh perajin bambu dan pelaku usaha olahan makanan berbahan singkong di Kecamatan Sumberrejo, Kabupaten Bojonegoro:

1. Pemasaran yang dilakukan kedua mitra sejauh ini hanya mengandalkan pada pameran serta pesanan dari penduduk lokal, belum memiliki rencana dan pemahaman pemasaran secara komprehensif dan efektif.

2. Kurangnya pengetahuan dan motivasi mitra dalam melakukan inovasi dan pengembangan produk baru.

Kebutuhan mitra untuk pendampingan persiapan launching maupun perencanaan bauran promosiyang tepatuntukmenarikminatkonsumen pada wisata edukatif yang baru terbentuk. Selain itu perlu pendampingan istilah-istilah pemasaaran dan promosi dalam bahasa inggris yang sering menjadi kendala saat berinteraksi dengan calon konsumen yang berbahasa asing. Hal ini cukup penting karena komunikasi yang baik merupakan awal untuk pengembangan bisnis hingga keluar daerah bahkan keluar negeri.

\section{METODE}

Solusi yang ditawarkan kepada mitra di Kecamatan Sumberrejo, Kabupaten Bojonegoro dalam pelaksanaan pengabdian kepada masyarakat bersama tim untuk mengatasi permasalahan yang berhubungan dengan pengembangan produk adalah mengenali siklus hidup produk, upaya inovasi, dan pengamatan pasar sebagai upaya menyediakan produk yang sesuai dengan minat masyarakat dan tren saat ini. Selain itu pada aspek pemasaran akan dilakukan penjelasan dan pelatihan terkait sarana promosi untuk memperluas pasar dan meningkatkan penjualan yang berdampak pada peningkatan penghasilan dan kesejahteraan mitra.

Pemberdayaan mitra yang diarahkan pada kegiatan penyusunan rencana pengembangan produk dan bauran promosi dilakukan dalam waktu satu bulan untuk realisasi program pengabdian bagi masyarakat. Pelatihan yang dilaksanakan oleh tim akan dilanjutkan dengan praktik oleh mitra didampingi oleh tim sehingga hasilnya diharapkan menjadi lebih baik dan menjadi sarana pemasaran yang efektif. 


\section{HASIL DAN PEMBAHASAN}

\section{Pretest}

Sebelum pelatihan dimulai, diadakan pretest oleh tim sebagai salah satu cara megukur pengetahuan mitra mengenai promosi dan sosial media sebelum diberi pelatihan. Mitra diminta menjawab beberapa pertanyaan yang telah disiapkan oleh tim. Pertanyaan-pertanyaan tersebut bersifat terbuka, artinya mitra bebas mendeskripsikan jawabannya tanpa dibatasi beberapa pilihan-pilihan jawaban.

Pertanyaan pertama yang diajukan oleh tim kepada mitra adalah jelaskan apa yang anda ketahui terkait promosi. Jawaban mitra dapat dilihat pada Tabel 1.

Tabel 1. Pengertian Promosi yang diketahui Mitra

\begin{tabular}{llc}
\hline No & \multicolumn{1}{c}{ Jawaban } & $\begin{array}{c}\text { Persentase } \\
(\%)\end{array}$ \\
\hline 1 & Menawarkan produk & 22,73 \\
2 & Memperkenalkan produk & 31,82 \\
3 & Pemasaran & 18,18 \\
4 & Terkenal di masyarakat & 4,54 \\
5 & Cara menarik perhatian konsumen & 13,64 \\
6 & Menjual produk & 9,09 \\
\hline \multirow{2}{*}{ Jumlah } & 100 \\
\hline
\end{tabular}

Tabel 1. menunjukkan bahwa sebesar $22,73 \%$ mitra menjawab menawarkan produk, 31,82\% mitra menjawab memperkenalkan produk, $18,18 \%$ mitra menjawab pemasaran, $4,54 \%$ mitra menjawab terkenal di masyarakat, sebesar 13,64\% mitra menjawab cara menarik perhatian konsumen, dan sebesar 9,09\% menjawab menjual produk. Hal ini menunjukkan bahwa beberapa mitra masih belum memahami pengertian promosi sebagai alat pemasaran dengan benar. Pengetahuan mitra masih belum komprehensif dan terbatas pada pengetahuan umum.

Pertanyaan kedua yang diajukan oleh tim kepada mitra adalah promosi apa saja yang sudah anda lakukan untuk mengelola usaha yang anda jalankan saat ini. Jawaban mitra dapat dilihat pada Tabel 2. Tabel tersebut menunjukkan bahwa sebesar $4,54 \%$ mitra menjawab membuat produk, $13,65 \%$ mitra menjawab sosialisasi masyarakat sekitar, $27,29 \%$ mitra menjawab media sosial, 4,54\% mitra menjawab dijual di sekolah, sebesar 9,09\% mitra menjawab belum ada, sebesar 4,54\% mitra menjawab membuka warung, 4,54\% mitra menjawab disetor ke tengkulak, 4,54\% mitra menjawab dri rumah ke rumah, 4,54\% mitra menjawab menyumbang doorprize ke acaraacara, $13,65 \%$ mitra menjawab pameran, 4,54\% mitra menjawab memberikan bonus, dan 4,54\% mitra menjawab brosur. Hal ini menunjukkan bahwa beberapa mitra masih belum melakukan promosi dengan tepat sesuai dengan kebutuhan untuk pemasaran produk.

Tabel 2. Promosi yang Sudah dilakukan Mitra

\begin{tabular}{llc}
\hline No. & \multicolumn{1}{c}{ Jawaban } & $\begin{array}{c}\text { Persentase } \\
(\%)\end{array}$ \\
\hline 1 & Membuat produk & 4,54 \\
2 & Sosialisasi masyarakat sekitar & 13,65 \\
3 & Media social & 27,29 \\
4 & Dijual di sekolah & 4,54 \\
5 & Belum ada & 9,09 \\
6 & Membuka warung & 4,54 \\
7 & Disetor ke tengkulak & 4,54 \\
8 & Dari rumah ke rumah & 4,54 \\
9 & Menyumbang doorprize ke & 4,54 \\
& acara-acara & 13,65 \\
10 & Pameran & 4,54 \\
11 & Memberikan bonus & 4,54 \\
12 & Brosur & $\mathbf{1 0 0}$ \\
\hline Jumlah &
\end{tabular}

\section{Pelatihan Bauran Promosi}

Permasalahan yang dihadapi mitra di Kecamatan Sumberrejo mengenai promosi merupakan target utama dalam program pengabdian kepada masyarakat ini. Pada tahap pertama tim memberikan beberapa materi mengenai pemasaran terkait dengan bauran promosi. Bauran promosi merupakan komponen penting dalam pemasaran dalam upaya untuk berkomunikasi dengan konsumen. Bauran promosi yang dibahas dalam pelatihan kali ini adalah iklan, promosi penjualan, penjualan personal, pemasaran langsung, dan hubungan masyarakat. Masing-masing bauran promosi tersebut memiliki ciri khas serta kelebihan dan kekurangan masingmasing.

Bauran promosi pertama yang dibahas dalam pelatihan adalah iklan. Iklan merupakan segala bentuk promosi berbayar terkait ide, barang dan jasa oleh sponsor tertentu. Kelebihan dari iklan adalah jangkauan luas, dapat diulang berkali-kali, ekspresif, dapat menampilkan visual suara dan gambar, serta dapat digunakan membangun image jangka panjang. Sedangkan kekurangan dari iklan adalah mahal, tidak spesifik, dan komunikasinya searah. Contoh iklan antara lain iklan di televisi, iklan di media online, outdoor semacam spanduk dan videotron, serta iklan di surat kabar atau majalah (Gambar 4).

Bauran promosi kedua yang dibahas dalam pelatihan adalah promosi penjualan. Bauran promosi merupakan insentif jangka pendek untuk mendorong penjualan produk atau jasa. Kelebihan dari promosi penjualan adalah menarik 
perhatian konsumen, menaikkan penjualan, dan mendapatkan respon yang cepat dari pelanggan. Sedangkan kekurangan dari promosi penjualan adalah jangka pendek, tidak seefektif iklan dan penjualan personal untuk hubungan jangka panjang dengan konsumen. Contoh promosi penjualan antara diskon, kupon, dan demo ditunjukkan pada Gambar 5.

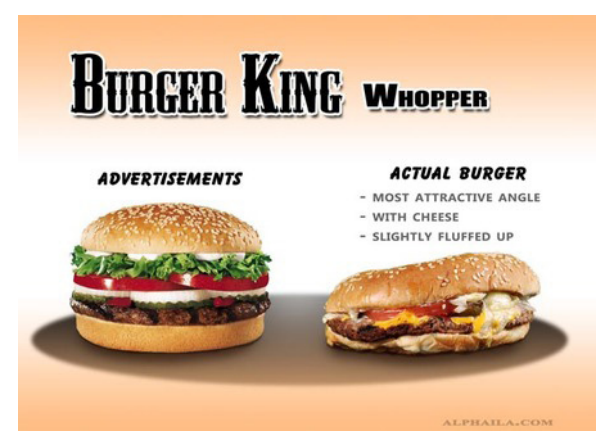

Gambar 4. Contoh iklan (Jenkins, 2011)

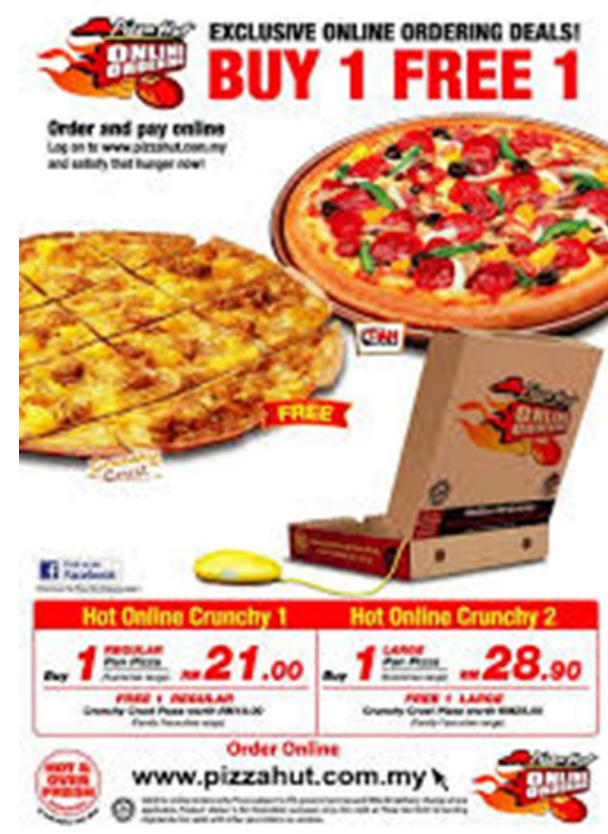

Gambar 5. Contoh Promosi Penjualan (Uprint, n.d.)

Bauran promosi ketiga yang dibahas dalam pelatihan adalah penjualan personal. Penjualan personal merupakan Interaksi personal dengan pelanggan oleh tenaga penjual untuk mendekati konsumen, meningkatkan penjualan, membangun hubungan dengan konsumen. Kelebihan dari penjualan personal adalah komunikasi dua arah sehingga langsung mengetahui kebutuhan konsumen dan membuat penyesuaian, membangun hubungan lebih mendalam. Sedangkan kekurangan dari penjualan personal adalah komitmen tenaga penjual lebih lama, tidak mudah diganti. Gambar 6 merupakan contoh penjualan personal antara lain presentasi dan pameran dagang.

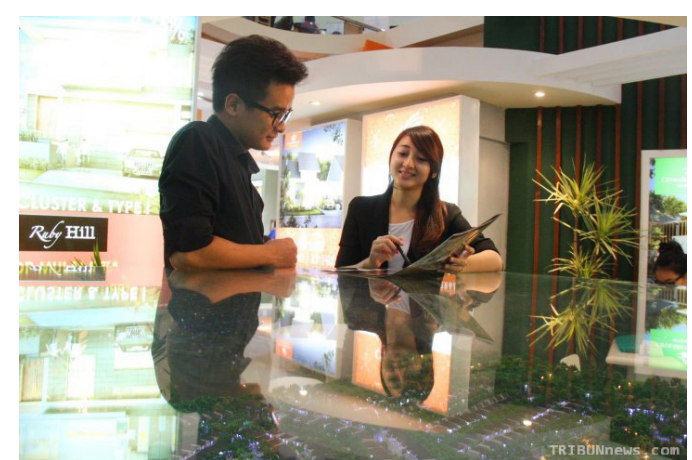

Gambar 6. Contoh Penjualan Personal (Nurmanto, 2018)

Bauran promosi keempat yang dibahas dalam pelatihan adalah pemasaran langsung. Pemasaran langsung membutuhkan keterlibatan secara langsung dengan konsumen untuk mendapat respon spontan dan membangun hubungan jangka panjang. Kelebihan dari pemasaran langsung adalah lebih spesifik dan langsung ke target. Contoh pemasaran langsung antara lain surat, email, katalog, dan media sosial ditunjukkan pada Gambar 7.

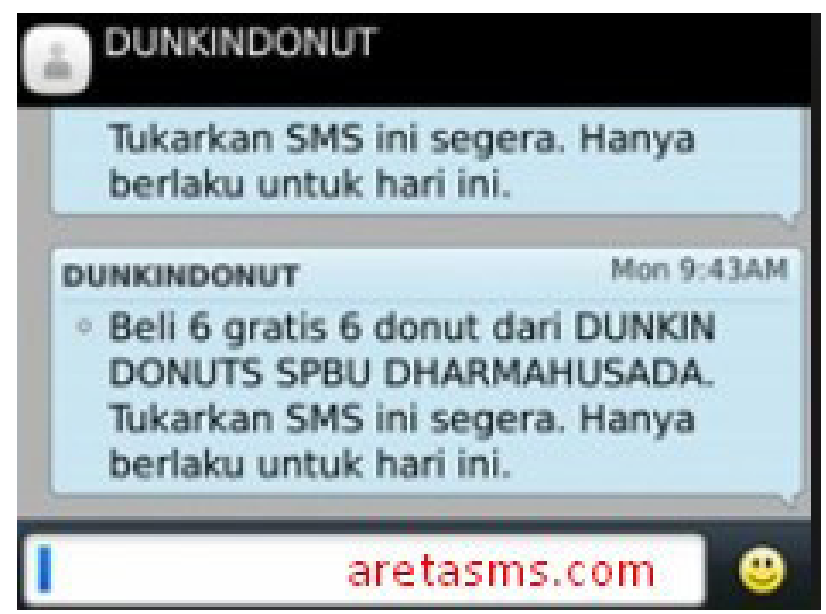

Gambar 7. Contoh Pemasaran Langsung (Aretasms, 2016)

Bauran promosi kelima yang dibahas dalam pelatihan adalah hubungan masyarakat. Hubungan masyarakat merupakan cara membangun hubungan baik dengan masyarakat untuk mendapat publisitas, citra yang baik, dan mengelola rumor yang tidak baik. Kelebihan dari hubungan masyarakat adalah lebih terpercaya daripada iklan, menjangkau yang tidak dapat dijangkau oleh tenaga penjual dan iklan. Contoh hubungan masyarakat antara lain sponsor, acara, dan press release ditunjukkan pada Gambar 8 .

Selain membahas mengenai contoh bauran 
promosi yang dapat digunakan sebagai alat pemasaran serta ketentuan penggunaannya, tim juga menyajikan informasi mengenai beberapa ketentuan yang harus ada dalam bauran promosi yang digunakan untuk bisnis. Ketentuan tersebut terkait dengan budget, target market dan tujuan promosi, serta tugas harian hingga bulanan yang harus dilakukan dalam mengelola bauran promosi.

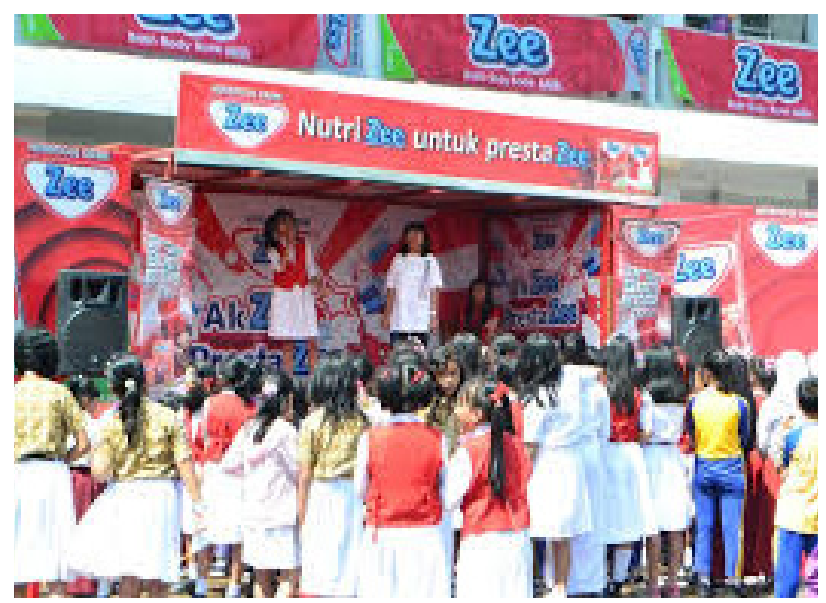

Gambar 8. Contoh Hubungan Masyarakat (TI3062, 2014)

\section{Post-test}

Setelah diberi penjelasan materi oleh tim, diadakan post-test oleh tim sebagai salah satu cara mengukur pengetahuan mitra mengenai bauran promosi setelah diberi pelatihan. Mitra diminta menjawab beberapa pertanyaan yang telah disiapkan oleh tim. Pertanyaan-pertanyaan tersebut bersifat terbuka, artinya mitra bebas mendeskripsikan jawabannya tanpa dibatasi beberapa pilihan-pilihan jawaban.

Pertanyaan pertama yang diajukan oleh tim kepada mitra adalah jelaskan apa yang anda ketahui terkait promosi. Jawaban mitra dapat dilihat pada Tabel 3.

Tabel 3. Pengertian Promosi yang diketahui Mitra

\begin{tabular}{lllc}
\hline No. & \multicolumn{1}{c}{ Jawaban } & \multicolumn{1}{c}{$\begin{array}{c}\text { Persentase } \\
(\%)\end{array}$} \\
\hline 1 & $\begin{array}{l}\text { Cara menjual dengan } \\
\text { pemasaran }\end{array}$ & bauran & 27,28 \\
2 & $\begin{array}{l}\text { Alat berkomunikasi dengan } \\
\text { pelanggan }\end{array}$ & 40,90 \\
3 & $\begin{array}{l}\text { Mengenalkan produk } \\
\text { masyarakat luas }\end{array}$ & ke & 31,82 \\
\hline Jumlah & & & 100 \\
\hline
\end{tabular}

Tabel 3. menunjukkan bahwa sebesar $27,78 \%$ mitra menjawab cara menjual dengan bauran pemasaran, 40,90\% mitra menjawab alat berkomunikasi dengan pelanggan, dan 31,82\% mitra menjawab mengenalkan produk ke masyarakat luas. Hal ini menunjukkan bahwa mitra sudah memahami mengenai bauran promosi. Jawaban yang diberikan mitra juga sudah mengerucut pada tiga pengertian, tidak lagi menyebar seperti pada jawaban saat pre-test. Sehingga dapat disimpulkan bahwa pelatihan mengenai pengertian bauran promosi berhasil.

Pertanyaan kedua yang diajukan oleh tim kepada mitra adalah promosi apa saja yang akan anda lakukan untuk mengelola usaha yang anda jalankan saat ini. Jawaban mitra dapat dilihat pada tabel berikut:

Tabel 4. Promosi yang Akan digunakan Mitra

\begin{tabular}{lll}
\hline No. & \multicolumn{1}{c}{ Jawaban } & $\begin{array}{c}\text { Persentase } \\
(\%)\end{array}$ \\
\hline 1 & Pemasaran langsung & 20 \\
2 & Hubungan masyarakat & 16,67 \\
3 & Penjualan personal (expo, & 13,33 \\
& pameran) & \\
4 & Promosi penjualan (kupon diskon) & 16,67 \\
5 & Iklan (brosur, media online) & 33,33 \\
\hline Jumlah & 100 \\
\hline
\end{tabular}

Tabel 4. menunjukkan bahwa sebesar $20 \%$ mitra menjawab pemasaran langsung, 16,67\% mitra menjawab hubungan masyarakat, $13,33 \%$ mitra menjawab penjualan personal (expo, pameran), $16,67 \%$ mitra menjawab promosi penjualan (kupon diskon), dan 33,33\% mitra menjawab iklan (brosur, media online). Hal ini menunjukkan bahwa mitra telah memahami berbagai jenis bauran promosi yang dapat digunakan sebagai alat pemasaran serta menggunakannya sesuai dengan kebutuhan masing-masing produk yang dipasarkan oleh mitra. Beberapa mitra merupakan pelaku usaha yang belum memiliki rancangan bauran promosi untuk memasarkan produknya, setelah dilakukan pelatihan dan mendapatkan materi dari tim mengenai bauran promosi dan penggunaanya maka mitra mulai membuat rencana untuk membuat bauran promosi yang sesuai dengan kebutuhan dan keinginan mitra untuk memasarkan produk yang dimilikinya.

\section{Diskusi dan Tanya Jawab}

Dalam forum diskusi dan tanya jawab, mitra nampak sangat antusias untuk membicarakan mengenai seluk beluk pemasaran khususnya bauran promosi dan permasalahan lain yang sering muncul dalam melakukan pemasaran. Forum diskusi dan tanya jawab merupakan sesi paling panjang dalam program pengabdian masyarakat karena hampir setiap peserta yang hadir memiliki pertanyaan terkait pemasaran usaha yang ingin didiskusikan dengan tim pelaksana.

Diskusi dan tanya jawab dibagi menjadi dua kelompok dengan satu orang dosen pendamping untuk tiap kelompok. Peserta dapat mengajukan 
pertanyaan kepada pendamping maupun sebagai bahan diskusi dengan peserta lain. Diskusi menjadi lebih lengkap karena latar belakang peserta yang berbeda-beda dan pemilihan bauran promosi yang berbeda pula.

Pertanyaan yang banyak diajukan terkait dengan hal-hal praktis yang sering muncul dan dihadapi oleh mitra. Pertanyaan yang muncul antara lain mengenai cara untuk membuat iklan dengan budget rendah, jenis bauran promosi yang tepat untuk jenis usahanya, pemanfaatan media social untuk sarana promosi, penggunaan bahasa yang baik dan benar untuk dicantumkan dalam akun media social, ketentuan dan syarat untuk berjualan di marketplace seperti shopee dan tokopedia. Tim pelaksana menjawab satu persatu pertanyaan dari para peserta dan mengajak berdiskusi peserta lain untuk memberikan solusi yang terbaik.

Sesi diskusi dan tanya jawab sekaligus memberikan feedback dan evaluasi untuk tim pelaksana dan peserta. Masukan yang diberikan peserta terkait dengan pelatihan lanjutan yang dibutuhkan mengenai fungsi pemasaran yang lain. Secara keseluruham, para peserta merasa senang dan puas dengan pelatihan yang diberikan dan merasa mendapat banyak manfaat dari sesi diskusi dan tanya jawab.

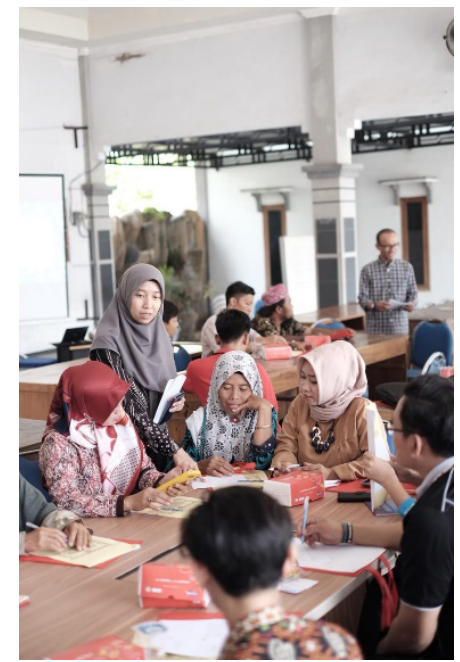

Gambar 9. Peserta Melakukan Diskusi

\section{KESIMPULAN DAN SARAN}

Selama proses kegiatan pengabdian masyarakat yang telah dilakukan, sebagian besar kegiatan berjalan lancar dan baik. Mitra mampu bekerja sama dengan baik dan merasa puas akan pelatihan yang diberikan oleh tim pelaksana. Beberapa yang menjadi program mitra selanjutnya adalah menindaklanjuti saran yang diberikan oleh tim pelaksana dan merencanakan iklan untuk beberapa mitra yang telah membentuk kelompok diskusi dan pengembangan iklan. Setelah pelatihan beberapa peserta pelatihan berkumpul untuk membahas kerjasama yang akan dilakukan untuk membuat iklan bersama-sama.

Materi yang disampaikan oleh tim mampu dipahami dengan baik oleh mitra, tercermin pada hasil pre test dan post test yang telah dilakukan menunjukkan hasil yang signifikan pada jawabanjawaban post-test. Pengetahuan dan minat mitra akan pemasaran melalui bauran promosi bertambah serta ditindaklanjuti dengan rencanarencana yang akan dilakukan oleh mitra sesuai dengan saran yang diberikan oleh tim.

Saran yang dapat diusulkan oleh tim pelaksana adalah pelatihan lanjutan terkait aspek pemasaran lain seperti saluran distribusi perlu untuk diadakan. Selain itu, perlu adanya evaluasi lanjutan mengenai iklan yang akan dibuat setelah pelatihan untuk beberapa waktu tertentu.

\section{UCAPAN TERIMA KASIH}

Penulis mengucapkan banyak terima kasih kepada Fakultas Vokasi Universitas Airlangga sebagai pemberi dana sehingga kegiatan pengabdian kepada masyarakat ini dapat berjalan dengan lancer. Selain itu kepada UMKM dan perangkat Kecamatan Sumberrejo, Bojonegoro sebagai mitra yang telah memberikan kesempatan kepada tim untuk berbagi pengetahuan dan pengalaman. Penulis menyatakan tidak ada konflik kepentingan dengan pihak-pihak yang terkait dalam kegiatan pengabdian kepada masyarakat ini.

\section{DAFTAR PUSTAKA}

Alfiyana, M. 2018. IRT ini Geluti Usaha Anyaman Bambu Turun-Temurun. Available from: http:// blokbojonegoro.com/2018/08/18/irt-ini-gelutiusaha-anyaman-bambu-turun-temurun/. Diakses pada 20 Februari 2019.

Alfiyana, M. 2018. Belum Diresmikan, Wisata Perajin Bambu Ramai Dikunjungi Wisatawan. Available from: http://blokbojonegoro. com/2018/12/13/belum-diresmikan-wisataperajin-bambu-ramai-dikunjungi-wisatawan/. Diakses pada 22 Februari 2019.

Aretasms. 2016. SMS Blast Target Lokasi Radius 500 M, Efektifkah ?. Available from: http:// www.aretasms.com/2016/08/sms-blasttarget-lokasi-radius-500-m.html. Diakses pada 22 September 2019.

Jenkins, B. 2011. 11 Hilarious Examples of False Advertising. Available from: https://www. oddee.com/item_97929.aspx. Diakses pada 
22 September 2019.

Nurmanto, F. 2018. Seberapa Handal Keterampilan Personal Selling Kamu. Available from: https://salesmaster.co.id/seberapa-handalketerampilan-personal-selling-kamu/. Diakses pada 24 September 2019.

Tl3062. 2014. Merancang dan Mengelola Komunikasi Pemasaran Terintegrasi. Available from: https://ti3602marketing.wordpress. com/2014/05/25/merancang-dan-mengelolakomunikasi-pemasaran-terintegrasi/. Diakses pada 25 September 2019.

Uprint. n.d. Tips Jitu Meningkatkan Penjualan Dengan Promosi. Available from: https:// uprint.id/blog/tips-jitu-meningkatkanpenjualan-dengan-promosi/. Diakses pada 27 September 2019. 